\title{
ANTIBODY RESPONSE TO NON-STREPTOCOCCAL ANTIGENS AS RELATED TO RHEUMATIC FEVER SUSCEPTIBILITY ${ }^{1}$
}

\author{
By JOSEPH M. MILLER, ${ }^{2}$ SIDNEY KIBRICK, ${ }^{3}$ AND BENEDICT F. MASSELL \\ (From the House of the Good Samaritan and the Research Division of Infectious Diseases, \\ Children's Medical Center, Boston, Mass.)
}

(Submitted for publication March 2, 1953; accepted April 7, 1953)

It is now well established that practically all initial attacks and subsequent recurrences of rheumatic fever are precipitated by antecedent Group A hemolytic streptococcal infection. Evidence to support this concept has been based on the close epidemiologic and bacteriologic association of acute rheumatic fever and streptococcal infection (1-9) as well as on the striking similarity of the antibody responses in both of these conditions (10). Despite this dependence of the rheumatic state upon prior hemolytic streptococcal infection, only a small portion of those exposed to this group of organisms actually develop rheumatic fever. Such disparity in the disease incidence indicates the importance of the host factor and suggests that susceptibility variables are important determinants of pathogenesis of rheumatic fever.

The purpose of this report is to explore the possibility that there exists in subjects with rheumatic fever a peculiarity of immune response which predisposes to the rheumatic state. Others have shown that hemolytic streptococcal respiratory infection complicated by rheumatic fever is associated with higher mean antistreptococcal antibody titers than is the uncomplicated illness $(11,12)$, and the conclusion from such data has peen that an immunologic hyperreactivity in such susceptible individuals may be fundamental for the development of rheumatic fever. Our studies have aimed to determine whether such supposed immunologic hyperreactivity of rheumatic subjects is confined to the streptococcus alone or whether one may also detect a more general augmentation of antibody response to non-streptococcal antigens as well. Preliminary results of such studies have been

\footnotetext{
1 Supported by a grant from the Helen Hay Whitney Foundation.

2 Research Fellow, New England Chapter, Arthritis and Rheumatism Foundation, 1950-51.

3 Post-doctorate Fellow, United States Public Health Service, 1950.
}

presented elsewhere (13). The present report is an extension of these earlier data.

\section{MATERIALS AND METHOD}

Influenza immunization: In preliminary experiments, influenza virus vaccine (Lederle) was used as a nonstreptococcal test antigen. Nine rheumatic fever patients hospitalized at the House of the Good Samaritan were selected for immunization, and eighteen children hospitalized for miscellaneous orthopedic conditions at the Children's Medical Center served as controls. All of the rheumatic fever subjects were in the convalescent stage of the disease and all had either an organic heart murmur or definite chorea. The rheumatic and control subjects were of comparable ages. Each child was given. a single intradermal injection of $0.1 \mathrm{cc}$. of a $1: 2.5$ dilution of influenza virus vaccine containing influenza A PR8 and influenza $B$ Lee strains. Blood specimens were obtained on all subjects immediately prior to the immunizing injection and at periodic intervals thereafter. The antibody response to these antigens was determined by both the hemagglutinin-inhibition and the complementfixation techniques. Maximum antibody levels, reached within four weeks after immunization, provided the basis for comparison of the response in the two groups tested. Antihemagglutinins were determined by the pattern method (14) using chicken erythrocytes, and complement fixing antibodies were determined by the method of Enders and Levens (15). The antigen suspensions for use in these tests were prepared in the allantoic sacs of ten day old chick embryos from PR8 and Lee B inocula supplied by Dr. J. F. Enders. After two days at $35^{\circ} \mathrm{C}$. the viruses were harvested and stored in the frozen state until needed.

Typhoid immunization: In a second series of experiments, fourteen children with rheumatic heart disease, hospitalized at the House of the Good Samaritan, were given a single $0.1 \mathrm{cc}$. intradermal dose of monovalent typhoid vaccine containing 100 million heat-killed organisms. As controls, ten children of comparable age with Legg-Perthes disease, hospitalized at the New England Peabody Home for Crippled Children, were similarly immunized. These children showed no evidence of rheumatic fever either by history or by physical examination. Other than mild local discomfort at the site of injection. there were no temperature elevations, no elevations in sedimentation rate, nor other untoward reactions in any of the subjects. In addition to a control blood sample: 
INFLUENZA VIRUS ANTIBODY RESPONSE

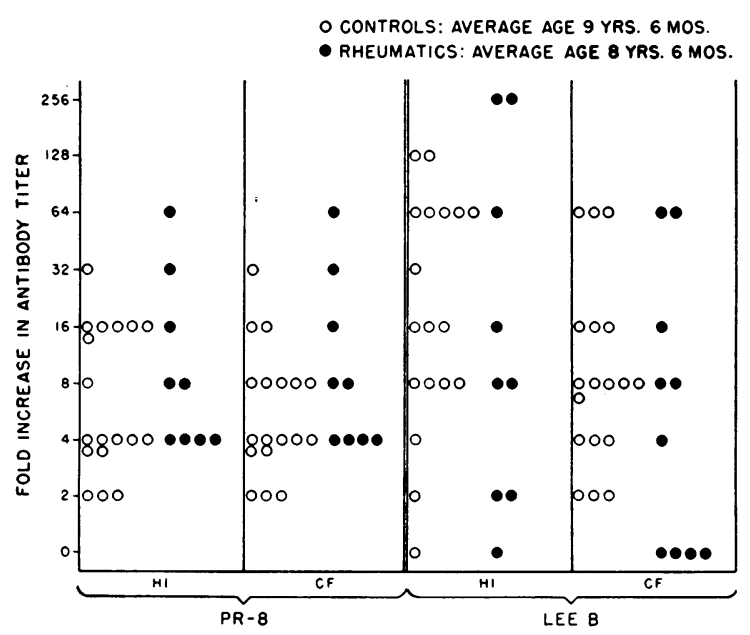

Fig. 1. Comparison of Peak Response to Influenza Immunization Using Hemagglutination Inhibition (HI) and Complement Fixation (CF) AntiBODY MEASUREMENT

taken on each subject prior to the immunizing injection, serial blood samples were drawn at weekly intervals over the next four weeks and at bi-weekly intervals for four additional weeks. Agglutinin titers were measured against both the $\mathrm{H}$ and $\mathrm{O}$ antigens. Antigen material used in the tests was prepared from strains of typhoid organisms obtained from the Department of Bacteriology of the Harvard Medical School. A standard serial dilution technique was used for antibody assay (16).

$$
\text { * }
$$

\section{RESULTS}

Influenza immunization: Since many of the subjects in both the rheumatic fever and control groups showed moderately high antibody levels prior to immunization, the antibody response attained after immunization has been plotted in terms of the fold increase produced by immunization (Figure 1). The scatter diagram in Figure 1 indicates that there was no significant difference in grouping of the antibody responses achieved by rheumatic and control subjects. Both groups of

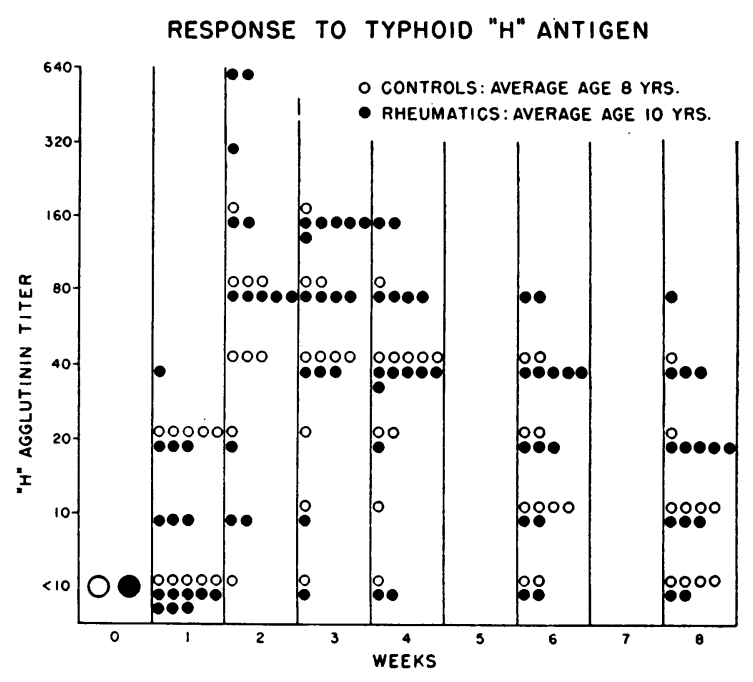

Fig. 2. Scatter Diagram of Anti-H Agglutinin Titers Following Typhoid Immunization

subjects showed a wide variation of response to influenza virus vaccine as reflected by the antibodies measured. Titers varied from no change following immunization to instances of a 256-fold increase.

A presentation of antibody data in terms of fold increase omits consideration of the effect of the pre-immunization titer on the final level attained. In general, the higher the initial titer, the less the fold increase following immunization. In Table I, therefore, there are presented composite pre- and post-immunization data from the same patients in terms of geometric mean antibody levels along with the titer fold increases as determined from these data. This table indicates that, despite the low mean pre-immunization titers of the rheumatic subjects, their antibody rise was, in general, less than that of the controls.

Typhoid immunization: Results of individual antibody levels following typhoid immunization have been plotted in the scatter diagrams of Figures 2 and 3 . In the case of the anti-H agglutinin,

TABLE I

Geometric mean antibody titers against influenza PR8 and Lee B

\begin{tabular}{|c|c|c|c|c|c|c|c|c|c|c|c|c|c|}
\hline & \multirow[b]{2}{*}{$\begin{array}{c}\text { No. of } \\
\text { cases }\end{array}$} & \multicolumn{3}{|c|}{$\begin{array}{l}\text { Anti-hemagglutinins } \\
\text { against PR8 }\end{array}$} & \multicolumn{3}{|c|}{$\begin{array}{l}\text { C. F. antibodies } \\
\text { against PR8 }\end{array}$} & \multicolumn{3}{|c|}{$\begin{array}{l}\text { Anti-hemagglutinins } \\
\text { against Lee B }\end{array}$} & \multicolumn{3}{|c|}{$\begin{array}{l}\text { C. F. antibodies } \\
\text { against Lee B }\end{array}$} \\
\hline & & Before & After & $\begin{array}{c}\text { Fold } \\
\text { rise }\end{array}$ & Before & After & $\begin{array}{c}\text { Fold } \\
\text { rise }\end{array}$ & Before & After & $\begin{array}{c}\text { Fold } \\
\text { rise }\end{array}$ & Before & After & $\begin{array}{c}\text { Fold } \\
\text { rise }\end{array}$ \\
\hline $\begin{array}{l}\text { Rheumatics } \\
\text { Controls }\end{array}$ & $\begin{array}{r}9 \\
18\end{array}$ & $\begin{array}{l}17.3 \\
35.9\end{array}$ & $\begin{array}{l}138 \\
237\end{array}$ & $\begin{array}{l}8.0 \\
6.6\end{array}$ & $\begin{array}{l}7.4 \\
9.3\end{array}$ & $\begin{array}{l}32.0 \\
52.8\end{array}$ & $\begin{array}{l}4.3 \\
5.7\end{array}$ & $\begin{array}{l}7.4 \\
8.3\end{array}$ & $\begin{array}{r}74.7 \\
155.2\end{array}$ & $\begin{array}{l}10.1 \\
18.7\end{array}$ & $\begin{array}{l}3.4 \\
3.7\end{array}$ & $\begin{array}{l}20.2 \\
33.3\end{array}$ & $\begin{array}{l}5.9 \\
9.0\end{array}$ \\
\hline
\end{tabular}




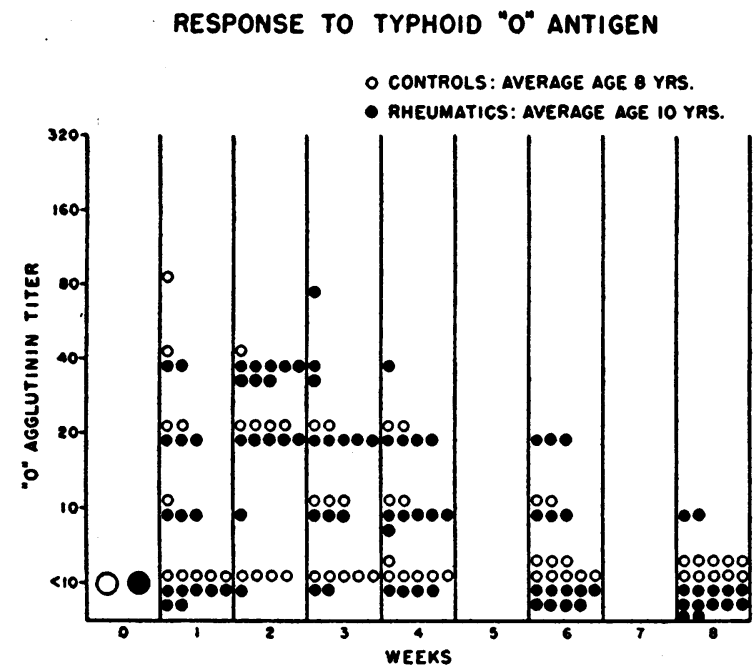

Fig. 3. Scatter Diagram of Anti-O Agglutinin Titers Following Typhoid Immunization

peak levels of response were reached after two weeks in both the rheumatic subjects and in the controls. As in the influenza studies, there is much overlapping in Figure 2 between the two groups with no clear cut difference in antibody response shown by the rheumatic fever patients. Similarly with the anti-O agglutinin (Figure 3 ) there was extensive overlapping of individual subjects of both groups. While the general height of antibody level attained for the O-agglutinin was moderately lower than the $\mathrm{H}$-agglutinin for both

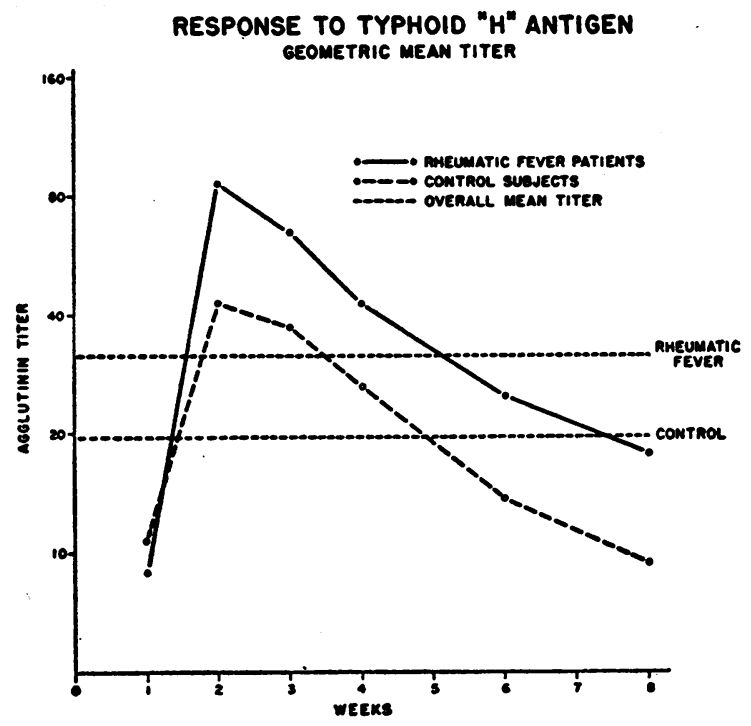

Fig. 4. Geometric Mean Titers at Weekly Intervals and Overall Mean Titer of H-Agglutinins FolLowing TyPhoId ImMUnization

groups, no distinct difference between the groups was discernible from the scatter diagram representation of the data.

The individual results were then tabulated by geometric means for each week after immunization, and these means are indicated in Figures 4 and 5. In Figure 4, the $\mathrm{H}$-agglutinin level of the rheumatic group of subjects over the course of eight weeks now appears higher than that of the

\section{RESPONSE TO TYPHOID "O" ANTIGEN \\ GEOMETRIC MEAN TITER}

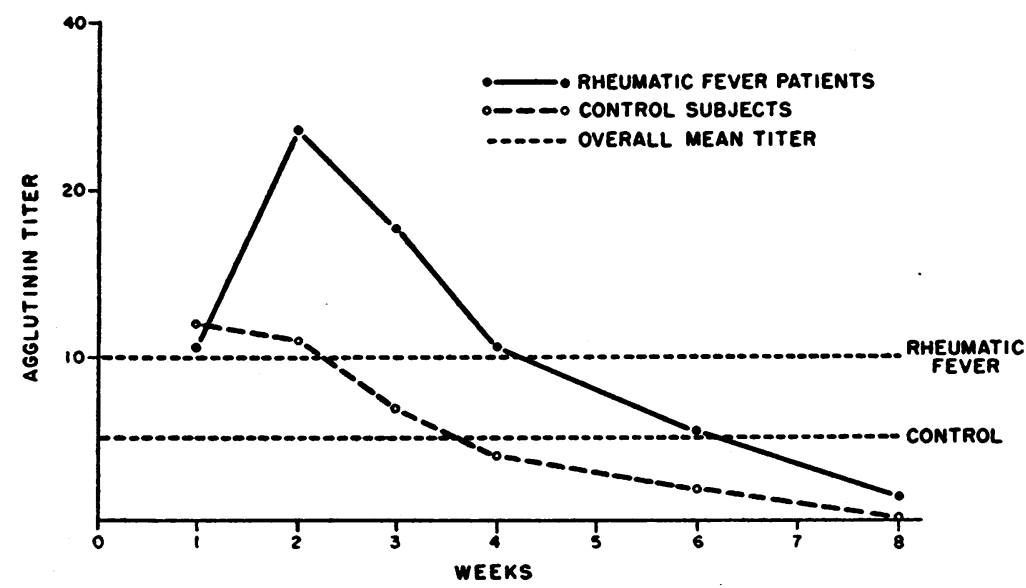

Fig. 5. Geometric Mean Titers at Weekly Intervals and Overall mean Titer of O-Agglutinins Following Typhoid Immunization 
control subjects. Likewise, the geometric mean of all the observations without regard for time interval after immunization is higher for the rheumatic fever patients. In Figure 5, the geometric means of the O-agglutinin titers for the rheumatic subjects were also somewhat higher than for the control subjects. These overall mean differences were found to be statistically significant. ${ }^{4}$

\section{DISCUSSION}

The results of these immunization studies do not confirm the hypothesis that rheumatic fever subjects show a general hyperreactivity of immune response, at least as judged by their response to the non-streptococcal antigenic stimuli of influenza virus and typhoid vaccine. In the instance of influenza virus immunization, initially elevated antibody levels prior to immunization may have obscured true differences of response from a uniform baseline, and for this reason typhoid immunization was considered to be a more valid method of studying these young subjects in the unsensitized state. None of the particular children immunized gave a history of previous typhoid infection or typhoid immunization, and baseline agglutinin levels confirmed the absence of typhoid antibodies. Although statistically significant, the observed difference between the mean titers is rather small and clinical conclusions of general hyperreactivity of rheumatic subjects appear hazardous. Also, the relatively small number of cases studied may hold for these particular individuals and not for rheumatic subjects in general.

A recent report by Creger, Choy, and Rantz (17) in which similar immunization studies, using mismatched blood, resulted in more striking increases of antibody response by rheumatic subjects warrants comment. Of the three rheumatic subjects demonstrating hyperreactivity of response to heterologous blood cells, the one subject showing the greatest rise in isoagglutinins had received a previous injection of mismatched blood and hence the response may have been, in part at least, the manifestation of a "booster phenomenon." Further, the use of mismatched blood in persons who already demonstrate isoagglutinins

\footnotetext{
4 Statistical analyses of these experiments were performed by Dr. William E. Reynolds, Assistant Professor of Preventive Medicine, Harvard Medical School.
}

to heterologous blood substances prior to challenge suggests that the criterion of an unsensitized state does not truly exist. Thus, even the first dose of group B cells given to a group A individual represents a "booster challenge" to the production of isoagglutinins.

On the other hand, the use of such antigenic boosters in previously sensitized persons may be the more appropriate means of detecting immunologic hyperreactions especially as related to hypersensitivity theories of rheumatic fever pathogenesis. If, as many have postulated, rheumatic fever develops in susceptible individuals only after repeated exposure to the hemolytic streptococcus, the experimental results of Creger, Choy, and Rantz are corroborating evidence. The work of Murphy and Swift (18) in animals is also in accord with such reasoning. It could follow that reimmunization of our subjects with repeated doses of typhoid vaccine might then result in more striking differences of antibody response and that such booster stimuli by the same antigen might ultimately demonstrate a more significant augmentation of immune response in rheumatic fever subjects. In the absence of such data and on the basis of our results with influenza and typhoid vaccines, however, it seems unwarranted to attribute any striking hyperreactivity of response to these antigens in the rheumatic subjects tested.

Such discrepancies of antibody response in somewhat comparable studies emphasize the lack of a uniform pattern of host hyperreactivity in rheumatic fever. Increased numbers of observations using varied measurements of immunologic indices, will be necessary before it is possible to define the role of immune responsiveness in rheumatic fever susceptibility.

\section{SUMMARY}

1. Twenty-three children in the convalescent stage of rheumatic fever were immunized with either polyvalent influenza virus vaccine or with monovalent typhoid vaccine. Twenty-eight nonrheumatic children of comparable age were similarly immunized and served as controls.

2. Results of influenza immunization, using complement fixing and hemagglutination inhibiting antibodies as indices of response, showed a wide variation in titer with no essential difference between the two groups. 
3. Whereas the geometric mean antibody to typhoid vaccine was slightly higher in rheumatic fever patients, there was extensive overlapping and scattering of individual responses in both groups over the eight week period of study.

4. On the basis of these observations using both a viral and bacterial antigen, it seems unwarranted to attribute to these rheumatic individuals any general hyperreactivity of immune response as an explanation for the development of the rheumatic state.

\section{ACKNOWLEDGMENT}

The authors are grateful to Miss Doris M. McCarthy for the technical assistance rendered in this study.

\section{REFERENCES}

1. Atwater, R. M., Studies in the epidemiology of acute rheumatic fever and related diseases in the United States, based on mortality statistics. Am. J. Hyg., 1927, 7, 343.

2. Schlesinger, B., The relationship of throat infection to acute rheumatism in childhood. Arch. Dis. Childhood, 1930, 5, 411.

3. Coburn, A. F., The Factor of Infection in the Rheumatic State. The Williams \& Wilkins Co., Baltimore, 1931.

4. Glover, J. A., and Griffith, F., Acute tonsillitis and some of its sequels: epidemiological and bacteriological observations. Brit. M. J., 1931, 2, 521.

5. Coburn, A. F., and Pauli, K. H., Studies on the relationship of streptococcus hemolyticus to the rheumatic process. J. Exper. Med., 1932, 56, 609.

6. Faulkner, J. M., Place, E. H., and Ohler, W. R., The effect of scarlet fever on the heart. Am. J. M. Sc., 1935, n.s. 189, 352.

7. Ditkowsky, S. P., Stevenson, E., and Campbell, J. M., An epidemic of rheumatic fever in a children's institution following an outbreak of acute tonsilitis. J. A. M. A., 1943, 121, 991.

8. Paul, J. R., and other contributors, The Epidemiology of Rheumatic Fever and Some of its Public Health Aspects. 2d ed., printed by the Metropolitan Life
Insurance Co. for the American Heart Association, 1943.

9. Coburn, A. F., and Young, D. C., The Epidemiology of Hemolytic Streptococcus During World War II in the United States Navy. The Williams \& Wilkins Co., Baltimore, 1949.

10. Coburn, A. F., and Pauli, R. H., Studies on the immune response of the rheumatic subject and its relationship to activity of the rheumatic process. J. Exper. Med., 1935, 62, 129.

11. Rothbard, S., Watson, R. F., Swift, H. F., and Wilson, A. T., Bacteriologic and immunologic studies on patients with hemolytic streptococcic infections as related to rheumatic fever. Arch. Int. Med., 1948, 82, 229.

12. Anderson, H. C., Kunkel, H. G., and McCarty, M., Quantitative antistreptokinase studies in patients infected with Group A hemolytic streptococci: A comparison with antistreptolysin and gamma globulin levels with special reference to the occurrence of rheumatic fever. J. Clin. Invest., 1948, 27, 425.

13. Miller, J. M., Kibrick, S., and Massell, B. F., Antibody response to non-streptococcal antigens as related to rheumatic fever susceptibility. Proc. New Eng. Cardiovasc. Soc., 1950-51, 46.

14. Hirst, G. K., Influenza in Diagnostic Procedures for Virus and Rickettsial Diseases. 1st ed., Am. Public Health Assoc., New York, 1948, p. 93.

15. Enders, J. F., and Levens, J. H., Mumps in Diagnostic Procedures for Virus and Rickettsial Diseases. 1st ed., Am. Pub. Health Assoc., New York, 1948, p. 139.

16. Wadsworth, A. B., Standard methods of the division of laboratories and research of the New York State Department of Health. 3d ed., The Williams \& Wilkins Co., Baltimore, 1947, p. 308 and p. 799.

17. Creger, W. P., Choy, S. H., and Rantz, L. A., Experimental determination of the hypersensitive diathesis in man. J. Immunol., 1951, 66, 445.

18. Murphy, G. E., and Swift, H. F., Induction of cardiac lesions, closely resembling those of rheumatic fever, in rabbits following repeated skin infections with Group A streptococci. J. Exper. Med., 1949, 89, 687.

\section{SPECIAL NOTICE TO SUBSCRIBERS}

Post Offices will no longer forward the Journal when you move.

Please notify The Journal of Clinical Investigation, Business Office, 622 West 168th Street, New York 32, N. Y. at once when you have a change of address, and do not omit the zone number if there is one. 